\title{
ПШДГОТОВКА ОФІЦЕРІВ-ЛІДЕРІВ ДЕСАНТНО-ШТУРМОВИХ ВІЙСЬК: ДОСВІД США ДЛЯ УКРАЇНИ
}

У статті розглянуто та проаналізовано сучасну підготовку офіцера-лідера а також формування та розвиток лідерських якостей офіцерів армії США та ВВНЗ Украӥни. Розкрито основні розбіжності у підготовиі військового лідера, простежено порядок формування та розвиток лідерської позииії офічерів Десантно-итурмових військ в армії США, узагальнено передовий досвід розвитку військового лідерства майбутніх офіџерів Десантно-штурмових військ. На основі порівняльного аналізу підготовки офіщерів Десантно-итурмових військ в США $і$ в Україні визначено проблемні питання щуодо впровадження системи лідерської підготовки у національну систему військової освіти.

Ключові слова: Десантно-итурмові війська; військова освіта; військове лідерство; офіцер-лідер; стандарти НАТО; підготовка військових фахівијв.

Постановка проблеми. У сучасних умовах перед країнами світу постають все нові вимоги до підготовки військових фахівців з урахуванням тих війн та військових конфліктів, які відбуваються у світі. Сучасний підхід до підготовки офіцерів диктує передумови для створення чітко вираженої поетапної підготовки, яка дозволить протягом усієї служби підвищувати професійний фах офіцерів та їх лідерські якості. А роль сучасного військового очевидна, вона неодмінно залежить від його характеру, компетентності та професіоналізму. За останні п’ять років у військово-професійній освіті нашої держави постала необхідність у визначенні ефективної системи підготовки військових лідерів та можливість впровадження ії у навчальний процес.

В процесі підготовки майбутніх офіцерів арміі США лідерство займає основне, вирішальне значення для проходження кар'єрної служби. Сучасний підхід до розвитку лідерів у Вест-Поінті грунтується на 200-річному досвіді підготовки лідерів та має ефективний результат 3 досвідом якого не можна сперечатися. Останнє зумовлює актуальність пропонованої розвідки, ऑii значимість у впровадженні в навчальний процес підходів до підготовки офіцерів-лідерів Десантно-штурмових військ (далі - ДШВ) Збройних сил України на досвіді підготовки лідерів в армії США.

\section{Аналіз останніх досліджень і публікацій.}

Проблемою військової освіти в Україні займалися різні науковці: Бойко О.В., Вітченко А.О., Зельницький А.О., Зубко В.M, Кудін В.О., Мітягін О.О., Нещадим М.I., Ничкало Н.Г., Ягупов В.В. та ін. Аналітичний огляд та порівняння системи військової освіти інших держав 3 системою військової освіти в Україні проводили Брижатий Є., Капосльоз Г., Кримець Л., Приходько Ю., Стрелецький А. та ін. Проте не зважаючи на значну 
кількість публікацій питання формування та розвитку лідерських якостей у офіцерів ДШВ Збройних сил України не висвітлено.

В армії США лідера вбачають як того, хто очолює процес впливу на людей, надаючи їм мету, спрямування, і мотивацію під час роботи з метою виконання місії та вдосконалення організації. Керівник армії - це будь-хто, хто в силу прийнятої ролі або покладеної на нього відповідальності, надихає та впливає на людей для досягнення організаційних цілей. Лідери армії мотивують людей, зосереджувати мислення i формувати рішення для більшого блага організації. Бути лідером набагато складніше, ніж просто давати накази. Вплив на інших може приймати різні форми. Виконуючи будь-яку дію або не виконуючи обов'язки - $є$ частиною впливу лідера на інших [5].

На думку американських спеціалістів у галузі національної оборони, оптимальною системою військово-професійної підготовки офіцерського складу $\epsilon$ система поетапного оволодіння навичками на різних рівнях [3].

Кожна країна має свої принципи підготовки військових лідерів. Однак історичний шлях та національні особливості неодмінно впливають на певні відмінності у системі відбору та підготовки офіцерів-лідерів а також на особливості в підході до розвитку лідерських якостей офіцерів, що зумовлені вимогами сучасними умовами ведення бойових дій.

Мета статті полягає у визначенні перспективних шляхів розвитку системи підготовки офіцерів-лідерів для ДШВ Збройних силах України на основі аналізу системи професійної підготовки офіцерів-десантників як лідерів в армії США.

Методи дослідження. У статті використано загальнонаукові методи аналізу наукової літератури 3 досліджуваної проблеми, систематизації та узагальнення, контент-аналізу.

Виклад основного матеріалу. Сьогодні широта вивчення проблеми та узагальнення кращого світового досвіду набуває багатоманітності в аспектах порівняльного аналізу сучасних шкіл професійної освіти.

Враховуючи різноманітність систем військової освіти різних країн, необхідно визначити ключові категорії, від яких буде залежати подальший порівняльний процес підготовки військових фахівців. Це структура підготовки офіцерських кадрів, підвищення кваліфікації та етапність у підготовці офіцерівлідерів.

Сьогодні у світі більшість міжнародних конфліктів не обходиться без залучення підрозділів ЗС США, які намагаються зайняти лідерську позицію у світі шляхом зміцнення військової могутності своєї держави. Американське військово-політичне керівництво за основу успіху у проведені операцій ставить комплектування збройних сил високопрофесійними фахівцями, а саме офіцерськими кадрами. Однак система підготовки офіцерських кадрів за різними спеціальностями помітно відрізняється одна від одної. Навчальні заклади Сухопутних військ США включають: школу роду військ, армійський командний коледж, підготовку офіцерів резерву, відділення перепідготовки 
командирів, офіцерів штабів, армійський військовий коледж, національний інститут стратегічних досліджень, університет національної оборони.

Структура навчання у вищих військових навчальних закладах є основними в системі підготовки кадрових офіцерів, що будується на повній середній освіті [2]. Після чого проводиться перепідготовка та підвищення кваліфікації офіцерів на курсах перепідготовки та вдосконалення, що функціонують при навчальних центрах і школах родів військ (сил) та служб.

Завдання Військової академії Сполучених Штатів (Вест-Поінт) полягає в тому, щоб «навчати та надихати кадетський корпус, щоб кожен випускник був уповноваженим лідером характеру, відданого цінностям Обов'язку, Честі, Країні та готовим до професійної кар'єри та служіння нації офіцером армії Сполучених Штатів» [9]. А розвиток характеру у підготовці офіцерів у військових навчальних закладах враховують як основну частину стратегії розвитку лідера.

Програма навчання розрахована на чотири роки [8]. Важливу роль під час прийому відіграє особиста бесіда із вступником, під час якої керівництво звертає увагу на мотивацію до подальшої служби. При заключному відборі розглядаються характеристики і рекомендації, отримані в середній школі. Обсяг дисциплін становить: на 1 курсі - 50\% годин, на 2 курсі - 30\% годин, на 3 курсі - 60\% годин, 4 курсі - 70\% годин. Крім того, у ході навчання досвід курсанта формується і базується на чотирьох рівнях лідерства: на 1-му році навчання - послідовність, за принципом «Роби як я». На 2-му році навчання особисте чи безпосереднє керівництво. На 3-му році - непряме керівництво. На 4-му році навчання - керівництво виконавчим / організаційним підрозділом.

Загалом викладають навчальні дисципліни, які розподілені на обов'язкові, за вибором тих, хто навчається, та факультативні. Профільні дисципліни вивчаються поглиблено. Однак крім профільних дисциплін та загальних положень лідерства 3 другого року навчання проводяться курси лідерства за різними напрямками [6]:

- базовий курс для лідерів (BLC);

- курс прогресивного лідера (ALC);

- курс старшого керівника (SLC);

- перша сержантська академія;

- академія майорів сержантів армії США (USASMA);

- академія старших сержантів;

Основна увага приділяється формуванню у курсантів трьох головних якостей, які притаманні американському військовому: компетентності, відповідальності і відданості своїй справі. Майбутній офіцер армії США виховується за принципом: бути високоінтелектуальним та освіченим.

Вступивши до вишу курсанти протягом першого року навчання опановують загально-військову підготовку. Результатом першого року навчання курсантів є отримання знань з загально-професійної компетентності та базові лідерські якості. Другий рік - отримання знань та практичне застосування набутих лідерських якостей при виконанні завдань за 
призначенням малим підрозділом (відділення). Третій та четвертий роки набуття спеціальних (фахових) компетентностей за професійним спрямуванням подальшої служби.

Програма розвитку лідерства у Вест-Поінті має п’ять основних цілей [7]:

1. Випускники повинні вміти демонструвати володіння основними військовими компетентностями, необхідними для перемоги у складному світі, та надихаються на військові та професійні досягнення.

2. Обов'язковий лідерський досвід викладачів що необхідний у формуванні основних військових компетентностей серед випускників.

3. Військові та інтелектуальні компетентності, необхідні для того, щоб бути ефективними інституційними лідерами в армії.

4. Генерація нових знань та ідей що забезпечить армію інтелектуальними ресурсами для вирішення військових проблем.

5. Використання у процесі навчання найбільш ефективних підходів за результатами оцінки роботи нових лідерів.

У ході розвитку та удосконалення лідерів розглядаються різні тематики навчання, що включені до програми лідерства: розвиток лідера та лідерства, характер та його розвиток, сприйняття та упередження, прийняття рішень, стійкість, мотивація, влада та вплив, теорія лідерства, консультування, переговори, динаміка команди, згуртованість, розвиток групи, управління конфліктами, організаційна справедливість, організаційна культура, організаційні зміни, соціалізація, міжкультурна компетентність та лідерство в екстремальних ситуаціях. Курсанти повинні навчитися та застосовувати знання про лідерство які вони отримали у досвіду роботи. Крім того, курсанти розробляють лідерське портфоліо, яке допомагає вдосконалити та інформувати про свій особистий підхід до лідерства. Портфоліо включає інформацію про роздуми над лідерством, самооцінку, особистий план розвитку (удосконалення) лідерства та теоретично обгрунтовану філософію лідерства.

Після завершення навчання у видовому училищі випускники отримують вищу загальну освіту, диплом бакалавра і первинне офіцерське звання другий лейтенант. Так як в академії Вест Поінт не передбачена спеціальна підготовка 3 певного роду військ то курсанти самостійно визначаються у майбутній спеціальності [4]. Перед призначенням на посаду молоді офіцери в обов'язковому порядку проходять курси підвищення кваліфікації у школах родів військ (сил) і служб тривалістю від чотирьох до восьми тижнів. Під час підвищення кваліфікації передбачене стажування у війська та участь у навчаннях Збройних сил [1].

Однак, спеціалізовані школи доступні тим, хто відповідає критеріям лідера. Програми підготовки та підвищення кваліфікації у школах дають можливість розвивати офіцера професійно, забезпечуючи навички, які допоможуть у кар'єрі військового. 


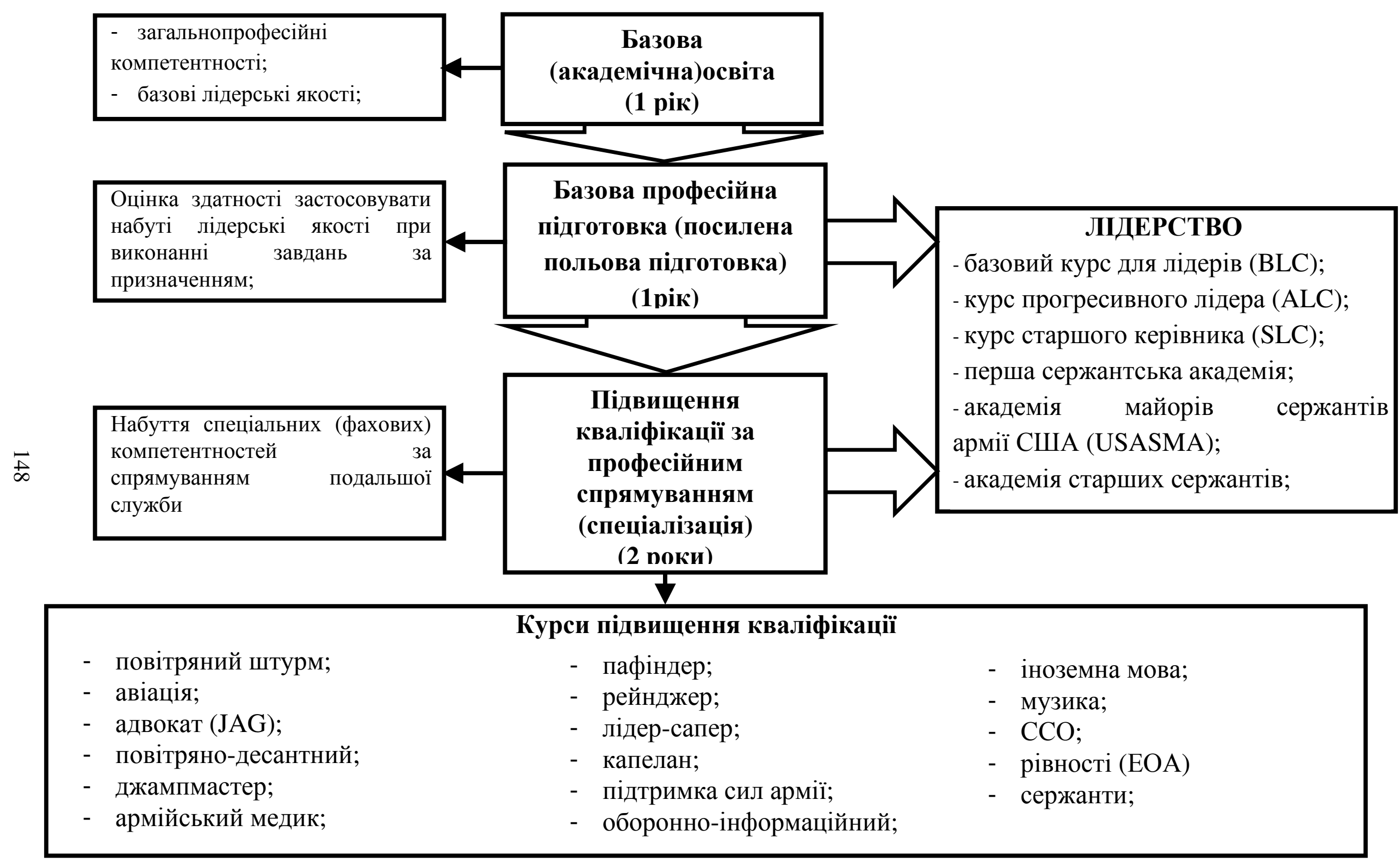

Рис. 1. Етапи підготовки офіцерів-лідерів армії США 
У підготовці майбутніх офіцерів армії США лідерській позиції надається особлива увага. Це проглядається 3 початком навчального процесу де передбачено вивчення та розуміння основних лідерських якостей військовослужбовця. А в подальшому - розвиток лідерських якостей кожної особистості відповідно до майбутнього професійного направлення (рис. 1).

Крім того, важливою частиною програми розвитку лідерів у Вест-Поінті $є$ курс Військового керівництва. Після закінчення якого курсантам пропонується впровадити та відпрацювати лідерські навички та знання, які вони опанували за час проходження курсу. Усі курсанти вищого класу займають керівні посади командування. Більше того, після закінчення молодшого курсу всі курсанти отримують можливість керувати підлеглими курсантами під час літніх польових тренувань, що імітують бойові умови. Потім, на старшому курсі у Вест-Поінті, вони займають додаткові керівні посади та проходять курс офіцерського складупризначений для зміцнення та розширення концепцій, засвоєних на курсі військового керівництва, а згодом відпрацьовують свої навички керівництва як в рамках командного складу Корпусу, так і в польових умовах [6].

На сучасному етапі підготовки військових фахівців в Україні підготовка офіцерів-лідерів здійснюється на курсах лідерства офіцерського складу (L-1; L2) вже після отримання професійної кваліфікації - офіцер тактичного рівня (рис. 2)., що значно відрізняється від підготовки лідерських якостей офіцерів в армії США, де підготовці лідерів приділяють значну увагу ще на початку військової кар'єри.

В армії США при розвитку лідерських якостей офіцерів звертають на самодисципліну, ініціативу, впевненість та рішучість у своїх діях, на фізичну та психічну стійкість, здатність швидко реагувати на різноманітні виклики та приймати рішення в стресових ситуаціях або під психологічним тиском. Крім того, офіцер-лідер повинен бути здатним до виконання своїх обов'язків у ситуаціях з підвищеною не безбекою не тільки для свого життя а й оточуючих.

В українській армії підготовка та розвиток лідерів здійснюється ж відповідно до освітніх кваліфікаційних вимог.

Результатом підготовки офіцері-лідерів у Десантно-штурмових військах Збройних сил України є:

- вивчення, розуміння та застосування у своїй професійній діяльності теорії і практики бойового застосування підрозділів в основних видах бою;

- порядок застосування штатного та приданого озброєння та військової техніки;

- організації і методиці підготовки та проведення занять 3 тактичної підготовки 3 десантно-штурмовим (аеромобільним, парашутно-десантним) підрозділом;

- формувати та розвивати у тих хто навчається: високу моральну та психологічну стійкість, організаторські здібності;

- здатність самостійно приймати рішення за будь-яких обставин;

- творчо мислити щодо застосування положень Бойових статутів, 


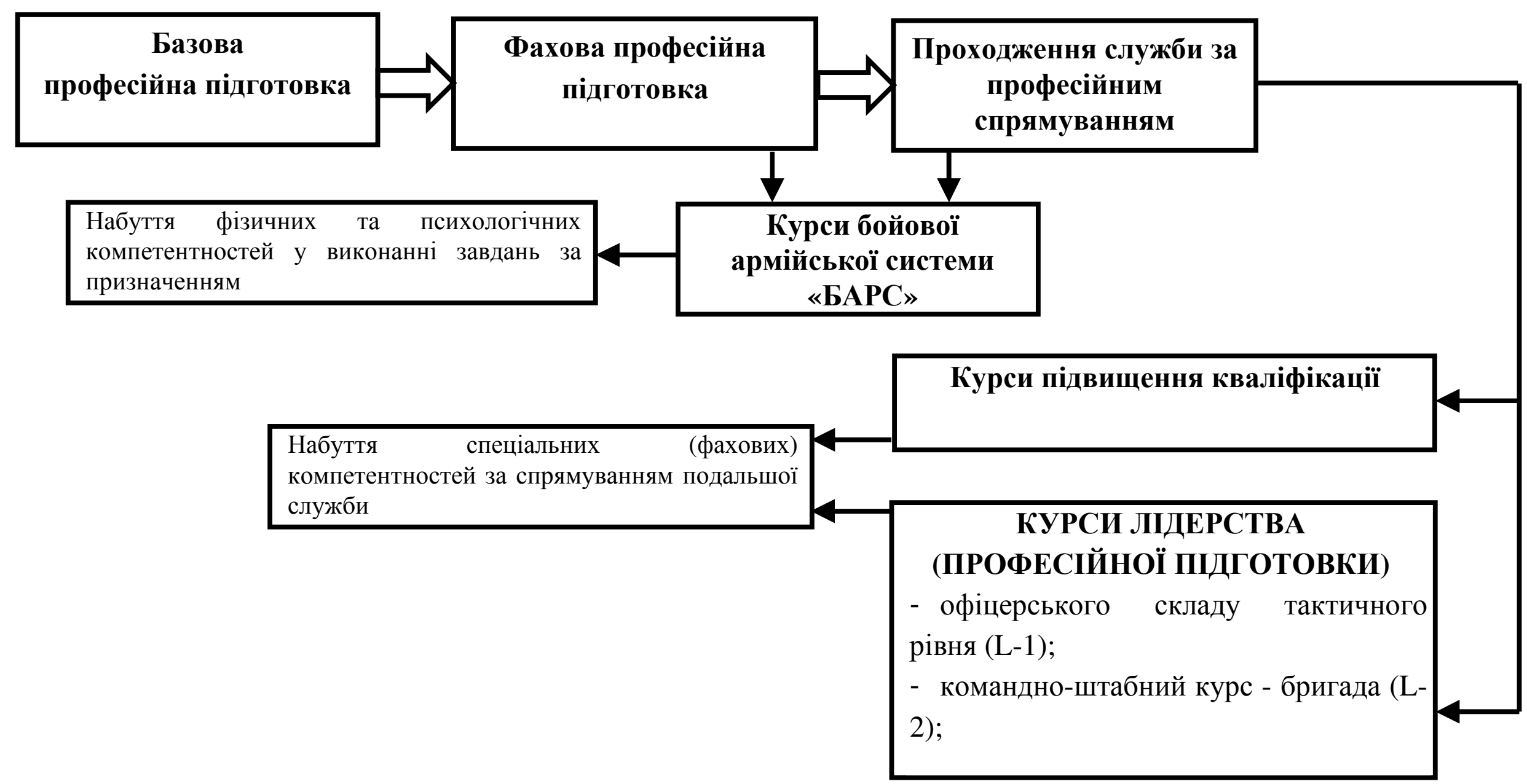

Рис. 2. Етапи підготовки офіцерів-лідерів Десантно-штурмових військ Збройних Сил України 
- розвивати ініціативу, командирську волю і самостійність в управлінні десантно-штурмовими (аеромобільними, парашутно-десантними) підрозділами в ході виконання бойових завдань та завдань за призначенням.

Висновки та перспективи подальших досліджень. Становлення сучасного офіцера-лідера у провідних арміях світу забезпечується не тільки використанням різноманітних освітніх інновацій, технологій навчання але й особливим підходом до розуміння феномену та актуальності лідерства у військовій сфері. На сьогодні існують значні відмінності та підходи до формування лідерських якостей та професійної компетентності офіцерів ДШВ в системі підготовки лідерів в армії США та Збройних силах України. Основним проблемним питання підготовки офіцерів в Україні є відсутність розгалуженої системи лідерської підготовки. На разі певні кроки у цьому напрямі зроблено й запроваджено курсову підготовку (Lкурси). Проте в межах цієї курсової підготовки в Україні питання набуття офіцерами лідерських якостей та компетентностей фактично не вирішується.

Поряд 3 цим, основним проблемним питанням щодо підготовки офіцерівлідерів у ДШВ ЗСУ також є:

- не визначено місце лідерської підготовки у системі військової освіти на кожному рівні;

- відсутнє чіткого розуміння етапів підготовки офіцерів-лідерів та розвитку їх індивідуальних лідерських якостей;

- відсутні необхідні критерії професійної придатності до проходження служби на офіцерських посадах у Десантно-штурмових військах ЗС України;

- відсутні критерії відповідного змісту та інструментарію для практичної реалізації лідерського потенціалу кожного офіцера.

Вирішення цих питань є важливим і актуальним з огляду на удосконалення системи кар'єрного зростання офіцерів (проходження служби), досягнення позитивних результатів у підготовці підлеглих до виконання завдань за призначення, формування команди військових професіоналів здатних виконувати складні спеціальні завдання які мають виконувати підрозділи ДШВ у сучасних умовах ведення бойових дій.

3 огляду на це потребує окремих досліджень питання щодо уточнення структури і змісту лідерської компетентності в у системі військової освіти, що дасть в подальшому можливість спроєктувати цілісний процес іiі розвитку в умовах післядипломної освіти офіцерів ДШВ Збройних сил України.

\section{ЛІТЕРАТУРА}

1. Вильданов М., Ветлугин. Р., Сухарева. О. Сухопутные войска США: комплектование и подготовка. Национальная оборона. №8 (2020). URL: https://oborona.ru/includes/periodics/armedforces/2017/0510/143421444/detail.shtml. _ (дата звернення: 13.09.2020).

2. Зінько Р.В., Шпак О.Б., Гавенко Б.І. Особливості навчання курсантів військових навчальних закладів. ЗНП ВІКНУ. 2013. №35(44). С. 186-197.

3. Стрелецький А. Система подготовки офицерских кадров в США. Зарубежное военное обозрение. 2006. С. 16-21.

4. Army leadership training. URL: https://www.goarmy.com/soldier-life/being-asoldier/ongoing-training/leadership-training.html. (дата звернення: 20.05.2020). 
5. Introduction to army leadership. Leadership track, section 1 URL: https://www.uakron.edu/armyrotc/MS1/24.pdf. (дата звернення: 13.09.2020).
6. Michael
D.
Developing
Leaders
at
West
Point. URL:

https://www.psychologytoday.com/us/blog/head-strong/201703/developing-leaders-west-point. (дата звернення: 15.09.2020).

7. Military program. URL:https://www.westpoint.edu/military-program. (дата звернення: 20.09.2020).

8. RedBook :.Academic Program class of 2020. New York : West Point, 2016. 679 p.

9. The U.S. military academy at West Point. URL: https://www.westpoint.edu. (дата звернення: 15.09.2020).

\section{REFERENCES}

1. Vil'danova M., Vetlugin. R., Sukhareva. A. Sukhoputnyye voyska SSHA: komplektovaniye i podgotovka. Natsional'naya oborona. №8 (2020). URL: https://oborona.ru/includes/periodics/ armedforces/2017/0510/143421444/detail.shtml. (Data obrashcheniya: 13.09.2020).

2. Zinka R.V., Shpak O.B., Gavenko B.I. Osobennosti obucheniya kursantov voyennykh uchebnykh zavedeniy. SNP VIKNU. 2013. №35 (44). S. 186-197.

3. Streletskiy A. Sistema podgotovki ofitserskikh kadrov v SSHA. Zarubezhnoye voyennoye obozreniye. 2006. S. 16-21.

4. Army leadership training. URL: https://www.goarmy.com/soldier-life/being-asoldier/ongoing-training/leadership-training.html. (дата звернення: 20.05.2020).

5. Introduction to army leadership. Leadership track, section 1 URL: https://www.uakron.edu/armyrotc/MS1/24.pdf. (дата звернення: 13.09.2020).
6. Michael
D.
Developing
Leaders
at
West
Point. URL:

https://www.psychologytoday.com/us/blog/head-strong/201703/developing-leaders-west-point. (дата звернення: 15.09.2020).

7. Military program. URL:https://www.westpoint.edu/military-program. (дата звернення: 20.09.2020).

8. RedBook:.Academic Program class of 2020. New York : West Point, 2016. 679 p.

9. The U.S. military academy at West Point. URL: https://www.westpoint.edu. (дата звернення: 15.09.2020)

\section{PЕЗЮМЕ}

Владимир Карпенко, Национальный университет обороны Украины имени Ивана Черняховского

\section{Подготовка офицеров-лидеров Десантно-штурмовых войск: опыт США для Украины}

В статье рассмотрено и проанализировано современную подготовку офищера-лидера, а также формирование и развитие лидерских качеств офицеров армии США и в военных вузах Украины. Раскрыты основные различия в подготовке военного лидера, прослежен порядок формирования и развитие лидерской позиции офищеров Десантно-итурмовых войск в армии США, обобщен передовой опыт развития военного лидерства будущих офищеров Десантноштурмовых войск. Определены проблемные вопросы по внедрению системы лидерской подготовки в национальную систему военного образования.

Ключевые слова: Десантно-итурмовые войска; военное образование; военное лидерство; офииер-лидер; стандарты НАТО; подготовка военных специалистов

\section{SUMMARY}

Volodymyr Karpenko,

National Defence University of Ukraine named after Ivan Chernyahovskyi 
The article considers and analyzes the current training of officer-leaders, as well as the formation and development of leadership qualities of officers of the US Army and universities of Ukraine. The main differences in the training of a military leader are revealed, the order of formation and development of the leadership position of Assault Troops officers in the US Army is traced, the best practices of military leadership development of future Assault Assault officers are summarized. Based on a comparative analysis of the training of assault officers in the United States and Ukraine, the problematic issues of implementing a system of leadership training in the national system of military education have been identified.

Introduction. In modern conditions, the countries of the world face ever new requirements for the training of military specialists, taking into account the wars and military conflicts that are taking place in the world. The modern approach to the training of officers dictates the preconditions for the creation of a clear step-by-step training, which will allow to increase the professional profession of officers and their leadership qualities throughout the service. And the role of the modern military is obvious, it certainly depends on his character, competence and professionalism. Over the past five years, in the military-professional education of our state, there has been a need to determine an effective system of training military leaders and the possibility of its implementation in the educational process.

Purpose. Identification of promising ways to develop the system of training officer officers for DShV Armed Forces of Ukraine based on the analysis of the system of professional training of paratrooper officers as leaders in the US Army.

Methods. The article uses general scientific methods of analysis of scientific literature on the researched problem, systematization and generalization, content analysis. $\backslash$

Result. The formation of a modern officer-leader in the world's leading armies is ensured not only by the use of various educational innovations, training technologies, but also by a special approach to understanding the phenomenon and relevance of leadership in the military sphere. Today, there are significant differences and approaches to the formation of leadership qualities and professional competence of DShV officers in the system of training leaders in the US Army and the Armed Forces of Ukraine. The main problem with the training of officers in Ukraine is the lack of an extensive system of leadership training. At present, certain steps in this direction have been made and course training $(L-$ courses) has been introduced. However, within the framework of this course training in Ukraine, the issue of acquiring leadership qualities and competencies by officers is not actually resolved.

In view of this, separate research is needed to clarify the structure and content of leadership competence in the military education system, which will further design a holistic process of its development in the postgraduate education of officers of the Armed Forces of Ukraine.

Originality. The main problematic issues regarding the training of officers-leaders in the landing troops of the Armed Forces are:

- the place of leadership training in the system of military education at each level has not been determined;

- there is no clear understanding of the stages of training of leadership officers and the development of their individual leadership qualities;

- there are no necessary criteria for professional suitability for service in officer positions in the Assault Troops of the Armed Forces of Ukraine;

- there are no criteria for the relevant content and tools for the practical implementation of the leadership potential of each officer.

Addressing these issues is important and relevant given the improvement of the career development system of officers (service), achieving positive results in preparing subordinates to perform tasks for the appointment, forming a team of military professionals capable of performing complex special tasks to be performed by DShV units in modern conditions of hostilities.

Conclusion. Requires separate research on the issue of clarifying the structure and content of leadership competence in the system of military education, which will further allow to design a holistic process of its development in the postgraduate education of officers of the Armed Forces of Ukraine.

Key words: Assault Troops; military education; military leadership; officer-leader; NATO standards; training of military specialists. 